OPEN ACCESS

Edited by:

Nils Borchard,

Natural Resources Institute Finland

(Luke), Finland

Reviewed by:

Rick Llewellyn,

Commonwealth Scientific and Industrial Research Organization

(CSIRO), Australia

Kelly Skinner

University of Waterloo, Canada

David Pannell,

University of Western

Australia, Australia

${ }^{*}$ Correspondence:

David Natcher

david.natcher@usask.ca

Specialty section:

This article was submitted to Climate-Smart Food Systems,

a section of the journal

Frontiers in Sustainable Food Systems

Received: 18 December 2020 Accepted: 06 April 2021

Published: 06 May 2021

Citation:

Natcher D, Ingram S, Solotki $R$, Burgess $C$, Kulshreshtha $S$ and Vold $L$ (2021) Assessing the Constraints to the Adoption of Containerized

Agriculture in Northern Canada.

Front. Sustain. Food Syst. 5:643366.

doi: 10.3389/fsufs. 2021.643366

\section{Assessing the Constraints to the Adoption of Containerized Agriculture in Northern Canada}

\author{
David Natcher $^{1 *}$, Shawn Ingram ${ }^{1}$, Ray Solotki ${ }^{2}$, Carl Burgess ${ }^{3}$, Suren Kulshreshtha ${ }^{1}$ and \\ Lindsey Vold $^{4}$
}

${ }^{1}$ Department of Agricultural and Resource Economics, University of Saskatchewan, Saskatoon, SK, Canada, ${ }^{2}$ Community Garden Society of Inuvik, Inuvik, NT, Canada, ${ }^{3}$ Cold Acre, Whitehorse, YT, Canada, ${ }^{4}$ College of Nursing, University of Saskatchewan, Saskatoon, SK, Canada

Considerable advancements are being made in containerized agricultural systems in the northern Canada. These systems are proving successful at overcoming the environmental constraints associated with cold climate food production and hold great promise for remote communities that suffer from high rates of food insecurity. However, if new technologies are to provide lasting and meaningful change for northern communities, critical attention needs to be directed to the variable and complex constraints that may limit their adoption and scalable success. To evaluate the potential uptake and use of containerized agriculture in northern Canada we employed the Adoption and Diffusion Outcome Prediction Tool. Twenty-two variables were ranked according to their influence on adoption. Six variables were then identified as being most constraining to the adoption of containerized agricultural systems, including upfront costs, expected profits, environmental impacts, complexity of the technology, trialability, and reversibility. We believe this type of pre-assessment is a critical, yet often over-looked step in technology transfer, and a necessary stage in assessing the scaling out potential for new food production technologies. This is particularly important for new food production technologies that demand significant financial investments that are wholly or partially irreversible.

\section{Keywords: technology adoption, food security, ADOPT, containerized agriculture systems, Northern Canada}

\section{INTRODUCTION}

Over the past decade, important technological innovations have been made in cold-climate food production. Arctic fisheries, for example, are employing new technologies that have enabled marine industries to capitalize on the sustainable and intelligent uses of aquatic natural resources (OECD, 2019). Through new product development and improved utilization methods, northern communities are finding novel ways of balancing food security, economic growth, and the protection of the marine environment (Huang et al., 2018).

Similar advances are being made in northern agriculture, where new technologies are proving successful at overcoming the environmental constraints associated with northern environments. These advances include novel containerized growing systems that employ vertical farming design, innovative instrumentation, and computer-controlled LED lighting systems. For regions like northern Canada, these innovations hold great promise for providing year-round access to fruits 
and vegetables, particularly in remote communities that suffer from high rates of food insecurity. Although most agree that containerized agriculture is not a panacea for the high rates of food insecurity experienced in northern Canada (Council of Canadian Academies (CCA), 2014), many do feel that these types of innovations are necessary for addressing the production constraints in the food insecurity equation.

Notwithstanding the innovations being made in containerized agriculture, it has yet to be determined what constraints may exist that could limit local adoption and scalable outcomes. Research conducted in other food insecure regions of the world have long found that despite the great potential for technological advancements to improve food production capabilities, there are often unforeseen cultural, economic, and political constraints that limit technological uptake (Feder and Just, 1985). However, in northern Canada the consideration of these factors has not kept pace with the rate of technological innovations being made, leaving new food producing technologies susceptible to rejection and disadoption.

In this paper we examine the constraints that could limit the adoption and scalability of containerized agriculture in northern Canada. This research was supported by the Arctic Council's Sustainable Development Working Group, which defines northern Canada as Yukon, Northwest Territories, Nunavik, Nunavut and Labrador. This specific study was based in Inuvik, Northwest Territories and was carried out in collaboration with the Community Garden Society of Inuvik (CGSI). The CGSI has operated a seasonal greenhouse (MayOctober) for more than 20 years and has proven successful at providing a seasonal source of fresh fruits and vegetables for community members. Despite that success, the current demand for fresh and affordable fruits and vegetables has outpaced supply, which has motivated the CGSI to consider the purchase of a containerized growing system that can contribute to a more sustainable and self-sufficient community food system in Inuvik.

Recognizing that the long-term adoption of a containerized growing system will be subject to a host of social, economic and environmental constraints, we set out to identify potential obstacles that may limit sustained adoption in Inuvik as well as the likely scalability to other communities in the Beaufort Delta Region. Scalability refers to the means of expanding the rate of adoption through social interaction and exchange between users (Pachico and Fujisaka, 2004). In this case, the potential users of containerized growing systems (i.e., the adopting population) may include community food groups, elected community councils, retailers, or community economic development corporations. Whereas, each of these users may be motivated by different reasons (i.e., profit among retailers) the high rates of food insecurity in northern Canada have fueled a common interest in these technologies (Kozachenko, 2020). To evaluate the potential uptake and use of containerized growing systems, we employed the Adoption and Diffusion Outcome Prediction Tool (ADOPT) (Kuehne et al., 2017) to estimate the likely rate and peak level of adoption. We also conducted an in-depth assessment of key variables that could either constraint or facilitate the adoption process. We believe this type of pre-assessment is a critical, yet often overlooked step in technology transfer, and a necessary stage in assessing the scaling out potential for new food production technologies in northern Canada. This is particularly important for new technologies that demand significant financial investments that are wholly or partially irreversible.

Following this introduction, we provide an overview of the agricultural sector in northern Canada, noting the status and limits for field-based production. We then review some of the innovations being made in northern food production technologies, including a more detailed description of containerized growing systems. We then describe the methods that were used to estimate the rate and peak levels of adoption. Our results are then presented along with an assessment of key variables that were identified as critical constraints to adoption. We conclude with a discussion of the major constraints that may limit the wide-spread adoption of containerized agricultural systems and make a call for greater collaboration between governments, industry, social scientists, and the northern communities that are most directly affected by the success or failure of these innovations.

\section{BACKGROUND}

Unlike the large commercial farms that are prominent in southern Canada, agricultural production in the Canadian north is conducted on small farms that average 66 hectares (ha) in area (Government of Canada, 2016). Most farming activities in the Canadian north occur in Yukon, Northwest Territories, and southern Labrador. The 2016 Census of Agriculture indicates that the number of farm operators in Yukon and Northwest Territories has been steadily increasing to its current estimate of 234 , with a total farm area covering $\sim 10,465$ ha. This includes 2,556 ha (24\%) devoted to field crops (Government of Canada, 2016). Despite the modest increases being made, the expansion of field-based agriculture in northern Canada is constrained by relatively short growing seasons and low seasonal growing temperatures. Ambient air temperatures in northern Canada are expected to rise due to global warming (IPCC, 2019), which may create new possibilities for increased field production, especially annual plants (Natcher, 2020). However, until northern Canada experiences prolonged growing seasons that are suitable to new crops and cultivars with a high yield potential, traditional field-based agriculture alone will be insufficient in providing year-round supplies of fruits and vegetables for northern communities. In the interim, fruits and vegetables will continue to be transported, at considerable cost, to northern communities to meet local food needs.

The cost of transporting fruits and vegetables to northern Canada has been subsidized by the Canadian Government since 2011, with the expectation that retailers will pass on the cost savings to consumers. Between 2011 and 2019 the Canadian Government, through Nutrition North Canada (NNC), spent roughly \$78 million annually to subsidize the northern transport of 30.4 million $\mathrm{kg}$ of perishable goods to eligible communities. This includes $\$ 25$ million (32\% of budget) to subsidize the 
shipment of 8.8 million $\mathrm{kg}$ of fruits and vegetables. However, a review of NNC found that the volumes and delivery times for fruits and vegetables were highly variable, resulting in compromised food quality and reduced consumer acceptability. Critics have also pointed out that government subsidies have done little to reduce retail food costs because price levels are left to the purview of retailers, over which NNC has no control (Galloway, 2017). These conditions have fuelled local speculation of price gouging by retailers. Despite the best intentions of NNC, high costs, coupled with poor retail quality, often removes fruits and vegetables from household food baskets; foods that are then replaced by non-perishable foods that lack equivalent nutritional value (Chen and Natcher, 2018). These conditions have added to what many characterize as a public health crisis in northern Canada (Council of Canadian Academies (CCA), 2014).

In response to their overdependence on imported fruits and vegetables, northern communities are exploring strategies that can lead to greater self-sufficiency in local food production. This includes the adoption of new agricultural technologies that are capable of providing year-round access to locally grown fruits and vegetables. For many northern communities, locally grown fruits and vegetables are seen as a promising alternative to imports that are often unaffordable, have compromised quality, or are simply unavailable in local retail outlets. For this reason, northern communities are turning to non-field-based forms of agricultural production to help meet local food demand.

For example, the community of Naujaat (population 1,200), in Nunavut has partnered with Growing Dome to develop a geodesic-shaped greenhouse that employs vertical hydroponic systems and hybrid raised dirt beds. The Growing Dome uses polycarbonate exterior walls, a solar powered air system, and thermal mass storage that is able to maintain temperatures of 30 degrees warmer than the outside air temperature. According to Growing Dome, residents of Naujaat have fully embraced this technology and now refer to it as their Green Iglu (Ryerson University, 2019).

Also in Nunavut, the community of Gjoa Haven (population 1,324) has entered into a partnership with the Arctic Research Foundation, Canadian Space Agency, National Research Council of Canada, and Agriculture and Agri-Foods Canada to pilot a hydroponic canister growing system known locally as Naurvik, or "the growing place." The system employs refurbished shipping containers to grow lettuce and microgreens year-round. Naurvik is powered primarily by wind and solar but has a backup generator when renewable sources are insufficient (Brown, 2020).

Another promising example is the Growcer hydroponic system that is used in Kuujjuaq, Nunavik (population 2,754). Also built inside a retrofitted shipping container, the Growcer food system is promoted as a "plug-and-play" canister growing system that supports a fully controlled year-round growing environment. The Growcer's state-of-the-art container system combines hydroponic technology with precision climate controls that are fully automated, and satellite controlled (The Growcer, 2020).

The CropBox is another containerized agricultural system that uses refurbished shipping containers. CropBox technology has been trialed in a controlled setting in Whitehorse, Yukon under variable weather conditions, and has proven successful in yielding up to $5,443 \mathrm{~kg}$ of greens and lettuce annually. The Kluane Research Station, which is located $220 \mathrm{~km}$ west of Whitehorse, is also testing the capacity of the Cropbox to be run exclusively from renewable energy ${ }^{1}$.

For their part, Canada's federal and territorial governments have proven supportive of these new innovations and have directed considerable financial resources to facilitate their development. Some of the more noteworthy funding programs include designated funds within Canada's $\$ 3$ billion federal Growing Forward II (GF2) program. The GF2 program supports advances in innovation and competitiveness in order to capitalize on emerging market opportunities (Agriculture and Agrifoods Canada (AAFC), 2013). The Canadian Agricultural Adaptation Program (CAAP) has also made available over $\$ 50$ million (2014-2019) to promote agriculture and agri-business development, including technological advancements such as new and innovative greenhouse designs (Agriculture and Agrifoods Canada (AAFC), 2019). The Canadian Northern Economic Development Agency has also invested in the design and development of LED-based greenhouses capable of providing year-round production of fruits and vegetables. The focus of the program has been on the engineering requirements for overcoming cold climate production. In addition to federal funding, territorial governments are making their own investments, for instance the Northern Food Development Program in NWT, which subsidizes the costs associated with the design and construction of greenhouse facilities that utilize renewable energy sources.

An array of containerized growing systems are being introduced across northern Canada in an effort to combat the high rates of food insecurity and to improve the general health and well-being of northern residents. These technologies, ranging from passive solar greenhouse designs, advanced hydroponic systems, remote monitoring, and satellite connectivity, are being adopted by northern communities. Yet if these technologies are going to reduce the high rates of food insecurity in the north, while generating local economic returns, their adoption will need to be sustained and made scalable for broader application.

\section{RESEARCH SITE AND METHODOLOGY}

\section{Research Site}

This research was based in the community of Inuvik, Northwest Territories. Inuvik is one of 8 communities located in the Beaufort Delta Region (BDR); the others being Aklavik (pop. 590), Fort McPherson (pop. 700), Paulatuk (pop. 265), Sachs Harbor (pop. 103); Tsiigehtchic (pop. 898), Tuktoyaktuk (pop. 898); and Ulukhaktok (pop. 396). Inuvik's population is roughly 3,536 residents, and includes Inuvialuit, Gwich'in and Métis peoples, as well as a non-Indigenous population. Inuvik is the administrative center in the BDR and due to limited road access, serves as the transportation hub for regional airlines. Like other regions in northern Canada, the climate of the

${ }^{1}$ Cold Acre. nd. Cropbox Canada. Available online at: https://www.coldacre.ca/ cropbox. 
BDR is characterized by long cold winters and short summers, with winter temperatures averaging between $-29^{\circ}$ and summer temperatures averaging $15^{\circ}$ Celsius $^{2}$.

Employment in the region is typically found in public service (e.g., Federal, Territorial and Indigenous governments), construction, extractive resource industries, and traditional subsistence sectors (e.g., hunting, trapping, fishing).

In 1998, a group of Inuvik residents self-organized and converted a local hockey arena into a seasonal greenhouse. Soon after, the Community Garden Society of Inuvik (CGSI) was born. Since that time, the Inuvik greenhouse has provided seasonal opportunities (May-October) for community members to grow fresh produce in one of the 170 individual growing beds. Members of the greenhouse are required to pay a \$25 annual membership fee, a $\$ 75$ plot fee, and are also expected to volunteer personal time for the upkeep of the greenhouse. In addition to individual memberships, there are also designated plots made available to community Elders, senior and youth group homes, and the Inuvik food bank.

Despite the success of the CGSI over the past 20 years, the current demand for fresh, affordable, and healthy produce in Inuvik has outpaced supply; a situation that has become even more pronounced during the Covid-19 pandemic. In response, CGSI is exploring the benefits of purchasing a containerized growing system that could provide year-round access to fruits and vegetables. However, prior to making that financial commitment, the CGSI recognized the need for a better understanding of the social and economic constraints that might undermine local adoption of a containerized system. It is in this context that our research was launched.

\section{Methodology}

Our methodology involved piloting the Adoption and Diffusion Outcome Prediction Tool (ADOPT) (Kuehne et al., 2017). ADOPT is a quantitative model that was developed by researchers at CSIRO in Australia that predicts the likely rate and peak level of adoption of agricultural technologies and management practices among target populations. ADOPT is structured around four general categories that influence adoption: characteristics of the technology; characteristics of the target population; relative advantages of using the technology; and the learning requirements relative to the advantages of the technology. These four categories include 22 variables that have been shown to influence, either positively or negatively, the rate and level at which new technologies are adopted (Kuehne et al., 2017). The model predicts the rate and peak level of adoption for a new technology as a function of the inputs the user chooses for each of the 22 variables. The tool requires users to choose a response for each variable from a 1 to 5 or in the case of some variables a 1 to 8 -point scale that best corresponds with the variable's perceived strength, direction, and influence on adoption. Each response is then represented numerically, with 1 indicating the most constraining and 5 or 8 the most facilitating to adoption. For example, if respondents felt the upfront cost

\footnotetext{
${ }^{2}$ Climate-Data.org, nd. Inuvik Climate. Available online at: https://en.climatedata.org/north-america/canada/northwest-territories/inuvik-15016/.
}

associated with containerized agriculture is a significant or even prohibitive constraint to adoption, a value of 1 would be assigned. Similarly, if respondents felt that containerized agriculture would generate moderate to maximum environmental benefits that would motivate or facilitate adoption, they would select a value as high as 8 on the scale.

Two versions of ADOPT have been developed, one Standard Version designed for studies conducted in developed countries and another Smallholder Version for developing country contexts. Since its development, ADOPT has been used by researchers to estimate the rate and peak levels of adoption of new cropping (Kuehne et al., 2012) and livestock systems (James and Harrison, 2016) by farmers, as well as by extension services and agricultural policy advisors (Addison and Walshe, 2015). For example, ADOPT was used to assess the adoptability of livestock greenhouse gas abatement techniques by ranchers in Australia. The tool proved informative to ranchers, policymakers and extension practitioners who were in a better position to consider the constraints that might limit adoption prior to new emission abatement schemes being introduced (James and Harrison, 2016).

In our study the Standard Version of ADOPT was employed and values were derived through a two-stage process. First, each of the 22 variables were considered by members of the research team where scores for each variable were reviewed, discussed, and ultimately agreed to. This allowed for deliberation and exploration of the factors that might facilitate or impede adoption. Second, we sought the expertise of others who have experience in containerized agriculture, including industry representatives $(N=3)$ and community leaders $(N=5)$ to further inform our input responses. After the expert respondents assigned values to each of the 22 variables, follow-up interviews were conducted with each respondent to assess which variables they considered to be most constraining or facilitating. Through this two-stage process a final list of scores and key variables were derived. These scores were then used as the input values to calculate the influence on the rate and peak level of adoption (Kuehne et al., 2017).

This scoring approach is to a certain extent subjective, in that the outputs are dependent on the judgments of the model's users. For this reason, a sensitivity analysis was used to determine how a step up or step down on the 5- or 8-point scales for each variable might affect adoption rates, holding all other variables constant. A step up refers to increasing the numerical score by one (more facilitating) and a step down refers to decreasing the numerical score by one (more constraining). This procedure allowed us to identify how adjustments made in any one variable might affect the overall level and rate of adoption. This also allowed the research team to evaluate potential strengths and weaknesses of containerized systems and explore strategies that could potentially remove or reduce constraints and promote scalable outcomes. This does not completely remove subjectivity, but it does nevertheless enable predictions to be made even in cases where uncertainty is high. For this reason, ADOPT was considered to be a useful tool that allowed for a structured analysis of the broader socio-economic factors that could hinder adoption (Kuehne et al., 2017). 
Given the relatively high financial costs of containerized growing systems, additional procedures were used to test the significance of cost and profit variables. The costs associated with containerized systems include the upfront cost of acquiring, transporting and installing the system and the downstream costs of labor and input requirements. In this case, income liquidity is inherently linked to the adoption process. Where income liquidity is sufficient, upfront costs tend to have less of an impact on the decision to adopt. Conversely, in cases where liquidity is low, and upfront costs exceed or strain available resources, adoption rates are typically constrained (Dercon and Christiaensen, 2011). However, if new technologies are expected to generate profit, liquidity constraints may be subordinated. In fact, much of the technology adoption literature emphasizes the positive influence of expected profitability when considering the adoption of new technologies (Bachmann et al., 2016).

In our analysis, the upfront costs included the initial capital expenditures needed to acquire, transport, and install the system in Inuvik. Based on published pricing information, the upfront costs of containerized systems used in northern Canada range from roughly $\$ 300,000$ to $\$ 800,000 \mathrm{CAD}$ depending on the level of technology used ${ }^{3}$. These costs do not include operational costs (e.g., labor, maintenance, and growing supplies) that will be required over the life of the system. For this analysis we assumed the most conservative cost estimate of $\$ 300,000$.

The CGSI does anticipate revenue being generated from the sale of fruits and vegetables. The anticipated annual yield estimates from a single containerized system is between 2,100 and $2,800 \mathrm{~kg}$ of produce, which would consist primarily of leafy greens and herbs. Based on existing retail food costs in Inuvik, the average sale price would be between $\$ 23.22 / \mathrm{kg}$ and $\$ 30.65 / \mathrm{kg}$, which could generate between $\$ 48,762$ and $\$ 85,820$ in gross sales annually. Based on the costs and anticipated income, we modeled the adoption of a containerized system under three different costprofit assumptions for each (Table 1), resulting in 9 scenarios. We did not calculate a loss of revenue scenario because we assumed that if the containerized system fell short of covering its operational costs, it would soon be disadopted unless it could be subsidized by some other source.

Although there are many social, political, and cultural factors that could also influence the adoption of any new technology, this procedure allowed us to evaluate how primary economic factors could either constrain or facilitate initial adoption. Additionally, we understood that profitability and upfront costs fluctuate between communities based on geography, population, retail demand, and the degree of financial assistance secured, and this procedure allowed us to account for these potential differences.

\section{RESULTS}

Scores from all 22 ADOPT variables are presented in Table 2. Of those 22 scores, 6 variables were identified by expert respondents as most influential. These variables include upfront

\footnotetext{
${ }^{3}$ For example, the costs of Naurvik system in Gjoa Haven, Nunavut utilizes renewable energy sources and its technologies are being trialed for potential use in future space exploration. This system represents the high price end for containerized growing systems.
}

TABLE 1 | Cost and profit scenarios.

\begin{tabular}{|c|c|}
\hline Cost scenario 1 & $\begin{array}{l}\text { The full upfront cost of the system is covered by a third party } \\
\text { (e.g., Federal or territorial government). }\end{array}$ \\
\hline Cost scenario 2 & $\begin{array}{l}\text { A moderate financial contribution is received from a third } \\
\text { party that covers } 50 \% \text { of the upfront costs. }\end{array}$ \\
\hline Cost scenario 3 & No third-party financial contribution is received. \\
\hline Profit scenario 1 & $\begin{array}{l}\text { Net profits are maximized through the direct sales of F\&V to } \\
\text { consumers as well as to retail and wholesale outlets. }\end{array}$ \\
\hline Profit scenario 2 & $\begin{array}{l}\text { Moderate sales are made through subscription services and } \\
\text { subsidies from Indigenous, territorial and federal government } \\
\text { contracts. }\end{array}$ \\
\hline rofit scenario 3 & Breakeven and cost recovery is achieved only. \\
\hline
\end{tabular}

costs, expected profits, environmental impacts, complexity of the technology, trialability, and reversibility. These variables were deemed the most relevant to containerized systems in northern Canada and were considered by participants as the most critical variables that might influence adoption.

\section{Variables 14 and 16: Cost and Profit}

All respondents identified the costs of the initial investment as a significant influence on the rate of adoption. The initial upfront costs, together with continuing costs of operations will constrain adoption if revenues do not provide a minimum breakeven return. In cases where costs outweigh profits, adoption may carry considerable risk. The adoption of the containerized system was felt to rest ultimately on the need to maximize expected profits, recoup the investment, and achieve tangible economic returns in the short run.

Based on the 9 cost-profit scenarios, we found that in cases where no upfront costs were required (i.e., funding secured from third party) and the systems generate maximum profits, the peak level of adoption was $27 \%$ over a 16 -year period (Table 3 ). This represents the greatest rate and level of adoption among the 9 scenarios. Conversely, in cases where communities are responsible for all upfront costs (i.e., no other sources of funding are secured), coupled with breakeven or cost recovery only, the peak rate of adoption is $3 \%$ and requires 18 years to be achieved. This represents the worst-case scenario.

In each of the 9 scenarios, the peak rate of adoption increases as profits grow and upfront costs are reduced. The results also suggest that potential profit had a more significant impact on predicted adoption levels than the relative upfront costs. This indicates that the adoption and scalability of containerized systems are more dependent on long-term profitability than short-term financial barriers. For instance, assuming no upfront costs, a step up to maximum profits from moderate profits increased predicted adoption levels by $16 \%$, while a step down response to breakeven profits decreased predicted adoption levels by $7 \%$. In comparison, even under maximum profits a step up response from moderate cost to no cost only increased predicted adoption by $7 \%$, while a step down to maximum cost levels decreased adoption by $3 \%$. However, while profitability has a greater relative impact on adoption levels than upfront costs, simultaneously reducing or eliminating upfront costs and increasing expected profits result in the greatest predicted levels of adoption. 
TABLE 2 | Variables included within the ADOPT model, including a brief description, assigned scores, reasoning, and the results of the sensitivity analysis (step-up/step-down).

\begin{tabular}{|c|c|c|c|c|c|c|}
\hline \multirow[b]{2}{*}{ ADOPT variable } & \multirow[b]{2}{*}{ Description } & \multirow[b]{2}{*}{$\begin{array}{l}\text { Mean response } \\
\text { (numerical }^{\text {value) }}\end{array}$} & \multicolumn{2}{|c|}{$\begin{array}{c}\text { Change in peak adoption } \\
\text { level }\end{array}$} & \multicolumn{2}{|c|}{$\begin{array}{l}\text { Change in time to peak } \\
\text { adoption (years) }\end{array}$} \\
\hline & & & $\begin{array}{l}\text { Step-up } \\
\text { response }\end{array}$ & $\begin{array}{l}\text { Step-down } \\
\text { response }\end{array}$ & $\begin{array}{l}\text { Step-up } \\
\text { response }\end{array}$ & $\begin{array}{l}\text { Step-down } \\
\text { response }\end{array}$ \\
\hline 1. Profit orientation & $\begin{array}{l}\text { The importance of profit maximization } \\
\text { to the target population. }\end{array}$ & $5 / 5$ & - & $-1 \%$ & - & 0.1 \\
\hline 2. Environmental orientation & $\begin{array}{l}\text { The importance of environmental } \\
\text { motivations to the target population. }\end{array}$ & $4 / 5$ & $2.6 \%$ & $-2.5 \%$ & -0.1 & 0.1 \\
\hline 3. Risk orientation & $\begin{array}{l}\text { The importance that the target } \\
\text { population places on minimizing risk. }\end{array}$ & $3 / 5$ & $0.7 \%$ & $-0.7 \%$ & 0 & 0 \\
\hline 4. Enterprise scale & $\begin{array}{l}\text { The target population has business } \\
\text { enterprises that could benefit from the } \\
\text { innovation. }\end{array}$ & $4 / 5$ & $2.5 \%$ & $-1.5 \%$ & -0.1 & 0.1 \\
\hline 5. Management horizon & $\begin{array}{l}\text { The target population that has a } \\
\text { long-term (+10 years) management } \\
\text { horizon. }\end{array}$ & $3 / 5$ & $0.5 \%$ & $-0.5 \%$ & 0 & 0 \\
\hline 6. Short-term constraints & $\begin{array}{l}\text { The proportion of the target } \\
\text { population under conditions of severe } \\
\text { short-term financial constraints. }\end{array}$ & $2 / 5$ & $0 \%$ & $0 \%$ & -0.8 & 0.8 \\
\hline 7. Trialing ease & $\begin{array}{l}\text { How easily the innovation can be } \\
\text { trialed on a limited basis before a } \\
\text { decision is made to adopt it. }\end{array}$ & $2 / 5$ & $0 \%$ & $0 \%$ & -1.2 & 1.2 \\
\hline 8. Innovation complexity & $\begin{array}{l}\text { Does the complexity of the innovation } \\
\text { affect evaluation and adoption? }\end{array}$ & $1 / 5$ & $7 \%$ & - & -1.3 & - \\
\hline 9. Observability & $\begin{array}{l}\text { The innovation is observable to others } \\
\text { in the region. }\end{array}$ & $3 / 5$ & $0 \%$ & $0 \%$ & -0.4 & 0.4 \\
\hline 10. Advisory support & $\begin{array}{l}\text { The proportion of the target } \\
\text { population that would use paid } \\
\text { advisors capable of providing advice } \\
\text { relevant to the project. }\end{array}$ & $5 / 5$ & - & $0 \%$ & - & 0.3 \\
\hline 11. Group involvement & $\begin{array}{l}\text { The proportion of the target } \\
\text { population that discusses local } \\
\text { issues. }\end{array}$ & $4 / 5$ & $0 \%$ & $0 \%$ & 0 & 0 \\
\hline $\begin{array}{l}\text { 12. Relevant existing skills } \\
\text { and knowledge }\end{array}$ & $\begin{array}{l}\text { The proportion of the target } \\
\text { population that will need to develop } \\
\text { substantial new skills and knowledge } \\
\text { to use the innovation. }\end{array}$ & $1 / 5$ & $0 \%$ & - & -0.5 & - \\
\hline 13. Innovation awareness & $\begin{array}{l}\text { The proportion of the target } \\
\text { population aware of the use or trialing } \\
\text { of the innovation in their district. }\end{array}$ & $4 / 5$ & $0 \%$ & $0 \%$ & -0.4 & 0.4 \\
\hline $\begin{array}{l}\text { 14. Relative upfront cost of } \\
\text { the innovation }\end{array}$ & $\begin{array}{l}\text { The size of the upfront cost of the } \\
\text { investment relative to the potential } \\
\text { annual benefit from using the } \\
\text { innovation. }\end{array}$ & $3 / 5$ & $2 \%$ & $-1 \%$ & 0 & 0.8 \\
\hline $\begin{array}{l}\text { 15. Reversability of the } \\
\text { innovation }\end{array}$ & $\begin{array}{l}\text { The extent to which the adoption of } \\
\text { the innovation can be reversed. }\end{array}$ & $2 / 5$ & $7 \%$ & $-4 \%$ & -0.2 & 0.3 \\
\hline $\begin{array}{l}\text { 16. Profit benefit in years } \\
\text { that it is used }\end{array}$ & $\begin{array}{l}\text { The expected profitability benefit of } \\
\text { the innovation in the years that it is } \\
\text { used. }\end{array}$ & $5 / 8$ & $12 \%$ & $-5 \%$ & -0.3 & 0.4 \\
\hline 17. Profit benefit in future & $\begin{array}{l}\text { The extent to which the use of the } \\
\text { innovation is likely to have additional } \\
\text { effects on future profitability. }\end{array}$ & $4 / 8$ & $12 \%$ & $-5 \%$ & -0.3 & 0.4 \\
\hline $\begin{array}{l}\text { 18. Time for future profit } \\
\text { benefits to be realized }\end{array}$ & $\begin{array}{l}\text { The amount of time after the } \\
\text { innovation is first adopted it takes for } \\
\text { effects on future profitability to be } \\
\text { realized. }\end{array}$ & N/A. & - & - & - & - \\
\hline
\end{tabular}




\begin{tabular}{|c|c|c|c|c|c|c|}
\hline \multirow[b]{2}{*}{ ADOPT variable } & \multirow[b]{2}{*}{ Description } & \multirow[b]{2}{*}{$\begin{array}{l}\text { Mean response } \\
\text { (numerical } \\
\text { value) }^{\mathrm{a}}\end{array}$} & \multicolumn{2}{|c|}{$\begin{array}{c}\text { Change in peak adoption } \\
\text { level }\end{array}$} & \multicolumn{2}{|c|}{$\begin{array}{c}\text { Change in time to peak } \\
\text { adoption (years) }\end{array}$} \\
\hline & & & $\begin{array}{l}\text { Step-up } \\
\text { response }\end{array}$ & $\begin{array}{l}\text { Step-down } \\
\text { response }\end{array}$ & $\begin{array}{l}\text { Step-up } \\
\text { response }\end{array}$ & $\begin{array}{l}\text { Step-down } \\
\text { response }\end{array}$ \\
\hline 19. Environmental impact & $\begin{array}{l}\text { The extent to which the innovation } \\
\text { impacts net environmental benefits or } \\
\text { costs and other non-monetary } \\
\text { factors. }\end{array}$ & $6 / 8$ & $10 \%$ & $-5 \%$ & -0.3 & 0.3 \\
\hline $\begin{array}{l}\text { 20. Time for environmental } \\
\text { impacts to be realized }\end{array}$ & $\begin{array}{l}\text { The amount of time after the } \\
\text { innovation is first adopted it takes for } \\
\text { the expected environmental benefits } \\
\text { or costs to be realized. }\end{array}$ & $4 / 5$ & $1 \%$ & $1.3 \%$ & 0 & 0.1 \\
\hline 21. Risk exposure & $\begin{array}{l}\text { The extent to which the use of the } \\
\text { innovation affects the net exposure to } \\
\text { risk. }\end{array}$ & $3 / 8$ & $6.5 \%$ & $-3 \%$ & -0.2 & 0.2 \\
\hline 22. Ease and convenience & $\begin{array}{l}\text { The extent to which the innovation } \\
\text { affects the ease and convenience of } \\
\text { the adopter in the years that it is used. }\end{array}$ & $3 / 8$ & $7 \%$ & $-3 \%$ & -0.2 & 0.2 \\
\hline
\end{tabular}

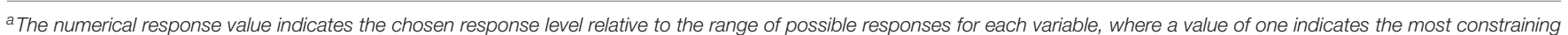

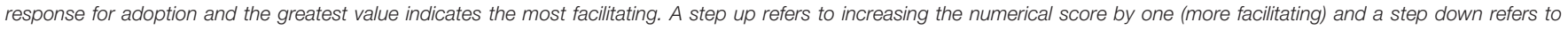
decreasing the numerical score by one (more constraining).

TABLE 3 | Predicted peak adoption levels and rates of adoption for nine cost-profit scenarios.

\begin{tabular}{|c|c|c|c|}
\hline & Maximum cost & Moderate cost & No initial cost \\
\hline $\begin{array}{l}\text { No profit } \\
\text { (breakeven) }\end{array}$ & $\begin{array}{l}3 \% \text { peak adoption, } \\
18 \text { years to } \\
\text { near-peak adoption }\end{array}$ & $\begin{array}{l}3 \% \text { peak } \\
\text { adoption, } 17 \text { years } \\
\text { to near-peak } \\
\text { adoption }\end{array}$ & $\begin{array}{l}4 \% \text { peak } \\
\text { adoption, } 17 \text { years } \\
\text { to near-peak } \\
\text { adoption }\end{array}$ \\
\hline Moderate profit & $\begin{array}{l}7 \% \text { peak adoption, } \\
18 \text { years to } \\
\text { near-peak adoption }\end{array}$ & $\begin{array}{l}8 \% \text { peak } \\
\text { adoption, } 17 \text { years } \\
\text { to near-peak } \\
\text { adoption }\end{array}$ & $\begin{array}{l}11 \% \text { peak } \\
\text { adoption, } 17 \text { years } \\
\text { to near-peak } \\
\text { adoption }\end{array}$ \\
\hline Maximum profit & $\begin{array}{l}\text { 17\% peak } \\
\text { adoption, } 17 \text { years } \\
\text { to near-peak } \\
\text { adoption }\end{array}$ & $\begin{array}{l}20 \% \text { peak } \\
\text { adoption, } 17 \text { years } \\
\text { to near-peak } \\
\text { adoption }\end{array}$ & $\begin{array}{l}27 \% \text { peak } \\
\text { adoption, } 16 \text { years } \\
\text { to near-peak } \\
\text { adoption }\end{array}$ \\
\hline
\end{tabular}

While peak adoption levels ranged from 3 to $26 \%$, time to peak adoption differed by only 2 years. The maximum cost scenarios, with either breakeven or moderate profit levels, were predicted to take roughly 18 years to reach peak adoption levels, whereas the maximum profit, no cost scenario was predicted to take 16 years to reach peak adoption levels (Figure 1). The remaining six scenarios were all predicted to take roughly 17 years to reach peak adoption levels. These projections reflect the significant constraint that upfront costs pose to the adoption of containerized agricultural systems in northern communities, even in cases where profits are generated.

\section{Variable 19: Environmental Costs and Benefits}

Containerized growing systems employ novel technologies that lessen the demand for imported fruits and vegetables.
The environmental benefits include reductions in energy requirements for transportation as well as a reduction in the production inputs (i.e., water, fertilizer). These benefits are often touted by manufactures when comparing the advantages of containerized systems over conventional agriculture and greenhouse cultivation. However, while containerized systems offer a number of environmental benefits compared to conventional cultivation, the local environmental impacts are not benign, and may be constraining for small and remote northern communities.

In 2019, the residential electricity rates in Inuvik were $\$ 0.396 / \mathrm{kWh}$, whereas the national average was $0.174 / \mathrm{kWh}$ (Community Garden Society of Inuvik, 2020). It is estimated that, on average, containerized systems require up to 5,000kilowatt hours per month, which for Inuvik would cost roughly $\$ 23,760 /$ year. Based on the CGSI revenue projections, this expense would absorb $28-49 \%$ of the total revenue generated from the sale of produce. Furthermore, diesel power generation is the primary, and in some cases only, source of electricity in BDR communities, meaning most of the electricity used would be derived from a non-renewable source. In 2017, only $39 \%$ of the NWT's energy was derived from hydroelectric generation, with $57 \%$ generated from diesel, $2 \%$ from wind, $2 \%$ from natural gas, and $1 \%$ from solar power (Government of Canada: National Energy Board, 2019). In response to the high incidence of energy insecurity, the Government of the NWT has introduced a draft 2030 Energy Strategy that calls for the installation of wind turbines and solar panels in small, off-grid communities to reduce their reliance on diesel power. If these renewable energy sources become more readily available, and are made compatible with containerized agricultural systems, this could increase the environmental benefits of using containerized systems. According to the ADOPT sensitivity analysis, adoption 


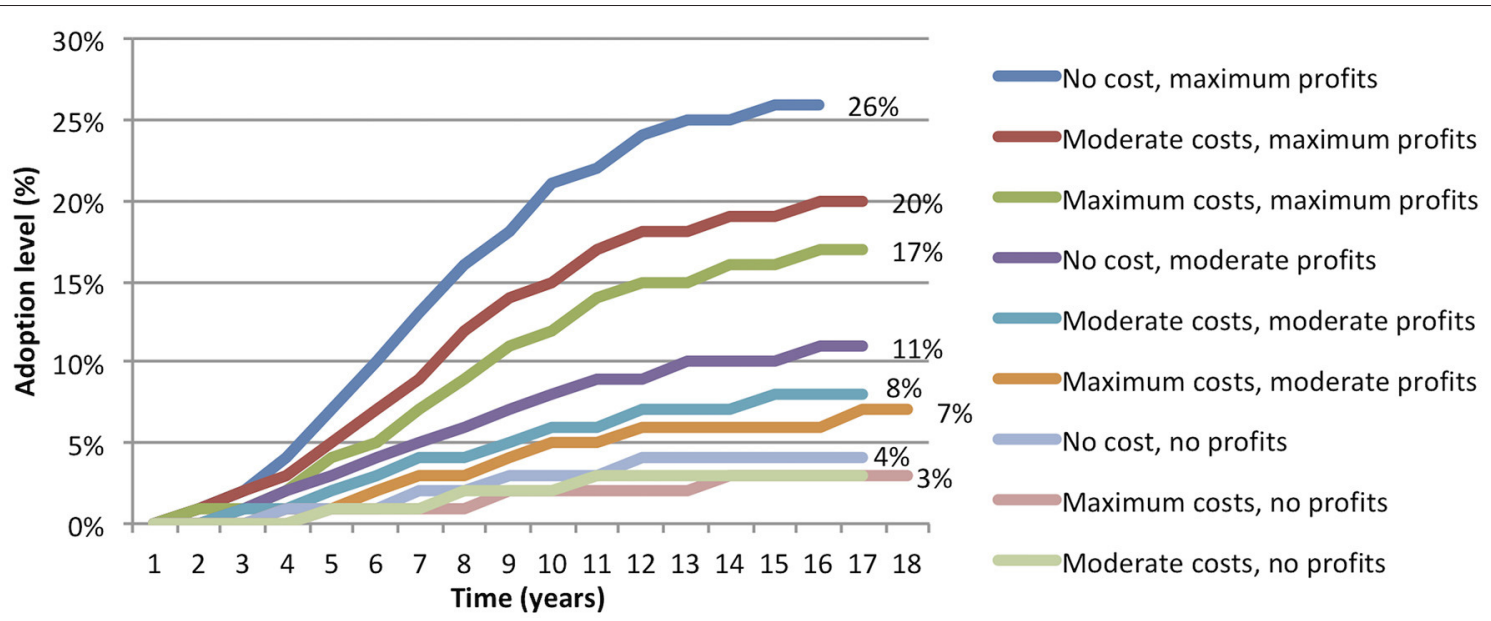

FIGURE 1 | Adoption curves of the predicted peak level and time to peak adoption levels for the nine cost-profit scenarios.

of containerized growing systems could then increase by as much as $10 \%$ (Table 2). However, if containerized systems remain dependent or increase dependence on diesel-generated power, adoption rates could decline by an estimated $5 \%$. While new renewable energy systems (solar and wind) may lessen dependence on diesel generated electricity, until those systems are more readily available and made compatible for containerized systems, communities will need to rely on diesel-based power generation into the foreseeable future.

In addition to heightened energy demand, containerized systems also draw on local water resources. While Inuvik's water is delivered via above $(16 \mathrm{~km})$ and below $(1 \mathrm{~km})$ ground pipes, other regional BDR communities rely exclusively on trucked water supplies (Environment Climate Change Canada, 2013). The Government of the NWT anticipates climate change will have a negative impact on water quantity, with detrimental changes caused by increased temperatures, extreme weather events, variability in precipitation, and impacts to critical infrastructure (Government of the Northwest Territories, 2019). These conditions have motivated other northern communities to prepare for water shortages by 2024 (Bakaic et al., 2018). Water quality is also subject to anthropogenic (e.g., faulty treatment systems) and non-anthropogonic (e.g., variable precipitation) disturbances. In 2018, seven communities in NWT had boil-water advisories, including Inuvik (Government of the Northwest Territories, 2019). Given the dependence on reliable and safe water resources, containerized systems may be vulnerable to short and long-term disruptions caused by constraints on other environmental inputs. Therefore, the containerized system may lessen total demand on global production inputs and transportation but may require additional inputs from local resources (e.g., energy, water). These new input demands may offset the environment benefits gained from local food production.

\section{Variable 8: Innovation Complexity}

The complexity and ease of use of containerized systems was identified as a significant variable that could constrain peak adoption levels. Containerized agricultural systems employ innovative technologies that have proven capable of overcoming the environmental constraints of northern agriculture. These technologies include sensor-controlled exhaust systems, sophisticated heating and air conditioning systems, fullspectrum LED lighting, integrated pest management systems, $\mathrm{CO}_{2}$ generation, and auto fill hydroponics with automatic nutrient dosage, all of which can be controlled through satellite connectivity and monitored from personal smartphone applications.

As innovative as these technologies are, we know from other adoption studies that the complexity and perceived ease of use are often major deterrents to technology adoption. Using the Technology Acceptance Model (TAM), Davis (1989) has shown that the degree to which a person believes a new technology is easy to use, and its interface is uncomplicated, will often dictate adoption. Parasuraman and Colby (2001, p. 41) have similarly found that when the complexity of a new technology feels overwhelming, and beyond the direct control of the user, it can create anxiety to the point of rejection. Furthermore, when the application of complex new technologies requires the acquisition of new skills, potential users often form attitudes toward the technology even before direct exposure (Bagozzi et al., 1992). If these attitudes are ill-formed or lack conviction, new technologies may have little positive effect.

Containerized growing systems demand a significant level of technical skills, including horticultural knowledge (i.e., identifying and treating plant nutritional deficiencies and toxicities), experience in propagating, transplanting, maintaining, and harvesting plants, familiarity with environmental control systems, and basic mechanical, electrical and plumbing skills. Whereas community members can be trained to maintain and monitor system components, if these systems malfunction and are inoperable for even short periods of time, communities may not be in the position to complete repairs. In these cases, the maintenance of these systems demands external assistance, which may be delayed by remote delivery that adds additional support costs. In the short term this creates 
further dependencies on external assistance but after sequential failings, may ultimately result in the disadoption of the system.

For these reasons, the complexity of containerized growing systems was weighted heavily as a constraining factor. In fact, due to its extreme ranking a step down effect was not possible since it received the highest constraining score (1/5). However, a step up response, representing a simultaneous decrease in technology complexity and increase in ease of use, was predicted to potentially increase peak adoption levels by $7 \%$ and reduce time to peak adoption by 1.3 years. However, if the complexity of the containerized systems exceeds local capacity and requires the learning of new skills (Variable 12), adoption and scalability may be limited.

\section{Variable 7: Trialability}

One strategy often used to overcome innovation complexity is through trialing opportunities. Trialability is the degree to which the technology can be experimented with and the level of exposure others have prior to making their own investment (Rogers, 2003). There has long been empirical evidence to show that the adoption rates of new technologies increase with direct experience or learning-by-doing (Warner, 1974; Natcher et al., 2016). This is particularly so for technologies that require high initial investment. Making containerized systems available for trial could alleviate user's potential concerns regarding the technology, thereby reducing adoption constraints and decreasing time to peak adoption. Through trialing, the decision to adopt containerized systems could be made following successive opportunities of information gathering, experiential learning, and hands-on experience (Jabbar et al., 2003). The tendency by which users of a new technology decide to adopt or reject a new technology can therefore be influenced by the extent to which it can be tested in order to confirm or refute its relative advantage, particularly when those opportunities are available at low or no cost (Pannell et al., 2006).

In the case of containerized agriculture, trialing opportunities are limited, and the costs involved are frequently prohibitive. In other trialing studies, the physical distance to the nearest adopter is often a critical factor for adoption (Lindner et al., 1982). In cases of close and sustained contact with early adopters, potential users have the opportunity to gain the necessary practical knowledge of the technology through observation and first-hand experience. However, in northern Canada, where the physical distance between communities is often significant, opportunities to trial containerized growing systems are often not available. With limited road access between BDR communities, travel typically occurs by air. In order to set up a trial for a containerized system, potential users would need to travel and arrange long-term accommodations which can be costly and difficult to secure, thus making the trialing of containerized systems costly, time consuming, and logistically difficult. For these reasons, trialing ease was predicted to be a key factor impacting how long it would take to reach peak adoption levels. The ADOPT sensitivity analysis supported this notion, as a step up response was predicted to decrease time to peak adoption by 1.2 years, while a step down response to difficult to trial increased time to peak adoption by 1.2 years. If there are limited opportunities to trial the system, or if trialing requires addition costs, the rate of adoption may be greatly diminished.

\section{Variable 15: Reversibility}

The distinction between reversible and irreversible investments is very relevant to containerized agriculture. Reversible technologies - such as the adoption of a hybrid seed or new planting technique-may require no or minimal long-term risk to income or other household/community assets (Feder and Umali, 1993). In such cases, disadoption is typically unproblematic in that users of the new technology can return to previous systems with little long-term disruption. With lower switching costs, the technology adoption decision is reversible which provides an advantage to riskier untested technologies (Chulkov, 2017).

Irreversible technologies, where initial costs are substantial, cannot be easily sold or transferred, and confer a high degree of uncertainty, are less easily abandoned (Ediger et al., 2005). In the case of containerized agriculture, significant financial commitments are required before the user knows for certain if it will prove advantageous. A decision can be made to disadopt but doing so would prove costly and may limit future investment opportunities. Secondly, advancements in containerized systems are occurring at such a pace that replacing one system for another is not practical. With technological advancements continually being made-either in terms of production capacity or their use of renewable energies-the containerized system purchased today may soon be outdated. Any new design elements (e.g., renewable energy sources, satellite connectivity) may be misaligned with a system's existing technology and not easily adapted or replaced (Bergen, 2016). Containerized agricultural systems are also not infinitely durable. While the container itself is well-suited to withstanding the environmental conditions of northern Canada, its components will ultimately need replacing when their performance begins to deteriorate. While short term benefits may be gained, containerized systems in the long term may create vulnerabilities through its irreversibility.

The significant sunk costs associated with disadoption of containerized systems expose user's to increased risk from adopting the technology. Increasing the degree to which the adoption decision is reversible, for example through trialing options or lower upfront costs, could reduce associated financial risks, which could promote adoption rates and levels. The ADOPT model predicted that a step up response in reversibility that simultaneously reduced user's risk exposure could increase adoption levels by $7 \%$ and decrease time to peak adoption 0.2 years. Conversely, a step down in reversibility and a corresponding increase in risk exposure was predicted to decrease peak adoption levels by $4 \%$ and slow adoption rates by 0.3 years. Given the upfront cost of containerized systems, the reversibility of these systems are limited, with disadoption likely resulting in the forfeit of the initial investment.

\section{DISCUSSION}

Our findings indicate that as the relative upfront costs of acquiring a containerized system are reduced, the rate and 
levels of adoption may increase. We captured this effect through the ADOPT analysis, which showed that the upfront cost of containerized systems was a significant and constraining factor to adoption. Based on this finding, the CGSI subsequently applied for and received funding from the federal government that will cover $80 \%$ of the capital costs for a containerized growing system. These funds will now be used to cover the purchase, transportation, and installation of a containerized system in Inuvik (spring 2021). By eliminating the upfront costs of the system, the likelihood and rate of sustained adoption in Inuvik has been improved.

However, our results also indicate that reducing or eliminating the upfront costs alone does not ensure the sustained adoption of a containerized system. Rather, profitability and the ability to generate revenue is an equally, if not more, critical variable to adoption. Lacking a revenue stream that can be used to cover the downstream costs of production, such as inputs, labor, and system maintenance, leaves containerized systems susceptible to disadoption. For this reason, the CGSI has developed a comprehensive business strategy that they hope will ensure its long-term liquidity. This business plan includes direct sales to consumers through subscription services, retail sales through community farmer's market events, and commercial sales through wholesale outlets and local restaurants. In these ways, the CGSI has responded to the two most significant financial constraints to containerized growing systems--upfront costs and profitability.

However, these responses alone do not eliminate all risk. For example, although the CGSI was able to secure $80 \%$ of the capital costs from the federal government, there have been other recent cases where the federal government has made significant financial investments in new technologies only to fall well-short of desired outcomes. Perhaps most notable in northern Canada has been the federal government's $\$ 3$ billion investment into community water treatment systems. Despite their efforts to provide the necessary infrastructure for safe drinking water and wastewater treatment, Indigenous communities continue to have "high risk" water systems, with $20 \%$ remaining under boil-water advisories (Government of Canada, 2020). While federal funding allowed for the acquisition of water treatment systems, other factors such as inadequate community infrastructure, persistent source water contamination, and inadequate training and administrative oversight have all been attributed to the limited uptake and application of these systems in Indigenous communities (Hyslop, 2014). Whereas, funding facilitated the placement of clean water systems in Indigenous communities, funding alone has not ensured sustained success. Therefore, in the case of containerized agriculture, it cannot be assumed that elimination or reduction of upfront costs will ensure sustained adoption.

Similarly, the profitability of containerized growing systems could be stymied by well-intentioned government policies. For example, the federal government's political imperative to improve food security has been advanced in large part through Nutrition North Canada (NNC). As noted above, NNC subsidizes the transportation costs for fruits and vegetables, with the aim to make fruits and vegetables more affordable and accessible to northern communities. As of 2019, 121 northern communities were eligible for subsidized food rates. This type of investment is considered by the federal government to be critical for reducing the high rates of food insecurity experienced across northern Canada. Yet the subsidies that NNC provides to retailers may actually distort market incentives for containerized production (Weisenfeld and Wetterberg, 2015). While well-intentioned, NNC may disincentivize local production by reducing the already thin profit margins of containerized systems--that is, the subsidized costs of imported fruits and vegetables could be lower than the actual costs associated with containerized food production.

Through this research, the CGSI has become aware of the financial risks and have responded through a comprehensive business plan. However, this business plan still does not overcome the other constraining factors, for example compounding local dependence on existing scarce resources (i.e., energy, water) that may be subject to future climate related stresses. These environmental constraints are an important consideration for northern communities as they may affect long-term viability of containerized growing systems and may inadvertently compound existing water and energy insecurities. Although some containerized systems are being developed with renewable energy options (e.g., solar and wind), communities will need to determine if there exists the necessary local skill sets for system maintenance. If not, the adoption of containerized systems may further entrench dependencies on external and potentially costly expertise.

Ultimately the sustained adoption and scalability of containerized agriculture systems in northern Canada will depend on the ability of communities to recognize and overcome the social, cultural, economic, and environmental constraints that may undermine the effectiveness of these technologies. The technology adoption literature is replete with examples of how even the most promising and innovative food producing technologies can be hampered by unanticipated constraints (Hartmann and Linn, 2008). The adoption of any new technology rests not only on maximizing production capacity or the nutritional utility that can be generated, but ultimately on the complexity of constraints northern communities face. Unlike other less capital-intensive technologies, the adoption of containerized growing systems is not easily reversible and has exceedingly high switching costs. Given the costs associated with containerized systems, together with the complexity of their instrumentation, the decision to adopt a containerized system will likely be made under considerable uncertainty.

\section{CONCLUSION}

Considerable advancements are being made in containerized growing systems. These technologies have proven successful at overcoming the environmental constraints associated with cold climate food production and have shown promise for alleviating the high rates of food insecurity experienced in the Canadian north. If new technologies are to provide lasting and meaningful change for northern communities, critical attention needs to be directed to the variable and complex constraints that may limit 
their adoption and scalable success. This was the intention of our collaborative research. Working directly with industry and community partners, we conducted an empirical preassessment of the constraints that may limit adoption of a containerized growing system prior to the financial investment being made. This type of collaboration has allowed for a more informed discussion that avoids the over-privileging of technological innovations by considering the various constraints that may undermine its sustained adoption.

Undoubtedly, communities in northern Canada will experience these conditions differently and this variability should be considered in any future assessments. Various contextual factors will affect the uptake of containerized systems and research teams need to understand how the reality of different social and geographical contexts might influence adoption. While containerized agricultural systems have a potential to provide year-round access to fruits and vegetables, these innovations need to be accompanied by a sensitivity to socio-economic dynamics of northern communities and an appreciation of the complexities that ultimately influence sustainable socio-technological outcomes in northern food production.

\section{DATA AVAILABILITY STATEMENT}

The original contributions presented in the study are included in the article/supplementary material, further inquiries can be directed to the corresponding author/s.

\section{REFERENCES}

Addison, P., and Walshe, T. (2015). Summary Report: The Cost-Effectiveness Protocol Used to Assist in the Prioritisation of the Second Phase of Reef Trust Investment. Final Report to the Department of the Environment, Australian Institute of Marine Science. Perth, NSW: Australian Institute of Marine Science. Agriculture and Agrifoods Canada (AAFC) (2019). Canadian Agriculture Adaptation Program. Available online at: https://www.mentorworks.ca/whatwe-offer/government-funding/research-development/caap/ (accessed October 10, 2020).

Agriculture and Agrifoods Canada (AAFC) (2013). AgriStability: Growing Forward 2 - Program Handbook. Available online at: https://www.agr.gc.ca/ eng/agricultural-programs-and-services/agristability/resources/agristabilitygrowing-forward-2-program-handbook/?id=1362577209732 (accessed October 10, 2020).

Bachmann, E., Natcher, D. C., Kulshreshtha, S., Baco, M. N., Akponikpe, P. B. I., and Peak, D. (2016). Profitability and institutional constraints to the adoption of fertilizer microdosing in Northwest Benin. Sustain. Agri. Res. 5, 11-23. doi: 10.5539/sar.v5n3p11

Bagozzi, R. P., Davis, F. D., and Warshaw, P. R. (1992). Development and test of a theory of technological learning and usage. Human Relat. 45, 660-686. doi: $10.1177 / 001872679204500702$

Bakaic, M., Medeiros, A., Peters, J., and Wolfe, B. (2018). Hydrologic monitoring tools for freshwater municipal planning in the Arctic: the case of Iqaluit, Nunavut, Canada. Envir. Sci. Pollut. Res. 25, 32913-32925. doi: 10.1007/s11356-017-9343-4

Bergen, J. P. (2016). Reversibility and nuclear energy production technologies: a framework and three cases. Ethics Policy Envir. 19, 37-59. doi: $10.1080 / 21550085.2016 .1173281$

Brown, B. (2020). This Greenhouse in a Sea Can in Gjoa Haven is Powered by Wind and Solar Energy. Available online at: https://www.cbc.ca/news/canada/

\section{ETHICS STATEMENT}

This research was approved by the University of Saskatchewan Behavioral Research Ethics Board (Beh-REB Certificate 2034) and received NWT Scientific Research License No. 16771 (issued by Aurora Research Institute-Aurora College, Inuvik, NWT).

\section{AUTHOR CONTRIBUTIONS}

DN was the principal investigator of the project and led the writing of the manuscript. SI conducted the ADOPT analysis. RS and $\mathrm{CB}$ provided community and industry insights. DN, SI, RS, CB, SK, and LV contributed to the writing of the manuscript. All authors contributed to the article and approved the submitted version.

\section{FUNDING}

Funding for this research was provided by Circumpolar Affairs, Crown-Indigenous Relations and North Affairs Canada.

\section{ACKNOWLEDGMENTS}

We gratefully acknowledge the support and contributions of Sarah Cox, Anthony McDermott and members of the Arctic Council-Sustainable Development Working Group.

north/western-nunavut-grows-vegetables-green-energy-1.5443823 (accessed January 29, 2020).

Chen, A., and Natcher, D. C. (2018). Greening Canada's arctic food system: local strategies for combating food insecurity. Canad. Food Stud. 6, 140-154. doi: 10.15353/cfs-rcea.v6i1.301

Chulkov, D. V. (2017). On the role of switching costs and decision reversability in information technology adoption and investment. J. Inform. Syst. Technol. Manage. 14. 309-321 doi: 10.4301/S1807-17752017000300001

Community Garden Society of Inuvik (2020). Arctic CropBox Business Plan: 2020-2024. Inuvik, NT: Community Garden Society of Inuvik.

Council of Canadian Academies (CCA) (2014). Aboriginal Food Security in Northern Canada: An Assessment of the State of Knowledge. Edited by the Expert Panel on the State of Knowledge of Food Security in Northern Canada. Ottawa: Council of Canadian Academies.

Davis, F. D. (1989). Perceived usefulness, perceived ease of use, and user acceptance of information technology. MIS Q. 13, 319-340. doi: 10.2307/249008

Dercon, S., and Christiaensen, L. (2011). Consumption risk, technology adoption and poverty traps: evidence from ethiopia. J. Dev. Econ. 96, 159-173. doi: $10.1016 /$ j.jdeveco.2010.08.003

Ediger, V., Madlener, R., and Kumbaroglu, G. (2005). Modeling technology adoption as an irreversible investment under uncertainty: the case of the Turkish electricity. Energy Econ. 27, 139-163. doi: 10.1016/j.eneco.2004.10.007

Environment and Climate Change Canada (2013). Water - How We Use It. Available online at: http://www.ec.gc.ca/eau-water/default.asp?lang=en\&n= 0bbd794b-1\#a8 (accessed November 25, 2020).

Feder, G., Just, R., and Zilberman, D. (1985). Adoption of agricultural innovations in developing countries: a survey. Econ. Dev. Cult. Change, 33, 255-298. doi: $10.1086 / 451461$

Feder, G., and Umali, D. L. (1993). The adoption of agricultural innovations: a review. Technol. Forecast. Soc. Change 43, 215-239. doi: 10.1016/0040-1625(93)90053-A 
Galloway, T. (2017). Canada's northern food subsidy nutrition North Canada: a comprehensive program review. Int. J. Circumpolar Health 76:1279451. doi: 10.1080/22423982.2017.1279451

Government of Canada (2016). Agricultural Census. Ottawa, ON: Government of Canada.

Government of Canada (2020). Government of Canada Announces \$1.5 Billion in New Investments for Clean Drinking Water in First Nations Communities. Ottawa: Indigenous Services Canada.

Government of Canada: National Energy Board, (2019). Provincial and Territorial Energy Profiles. Available online at: https://www.neb-one.gc.ca/nrg/ntgrtd/ mrkt/nrgsstmprfls/index-eng.html (accessed November 25, 2020).

Government of the Northwest Territories, (2019). Past Boil Water Advisories. Available online at: https://www.hss.gov.nt.ca/en/services/boil-wateradvisories/past-boil-water-advisories (accessed November 25, 2020).

Hartmann, A., and Linn, J. F. (2008). Scaling Up: A Framework and Lessons for Development Effectiveness From Literature and Practice, Working Paper. Washington, DC: Wolfensohn Center for Development at Brookings. doi: $10.2139 /$ ssrn. 1301625

Huang, T. H., Wang, P. W., Yang, S. C., Chou, W. L., and Fang, J. Y. (2018). Cosmetic and therapeutic applications of fish oil's fatty acids on the skin. Marine Drugs 16:256. doi: 10.3390/md16080256

Hyslop, K. (2014). A fresh fix for unsafe water on First Nations reserves. The Tyee. Available online at: https://thetyee.ca/News/2014/01/13/Water-on-Reserves/? utm_source=daily\&utm_medium $=$ email\&utm_campaign $=130114 \quad$ (accessed November 22, 2020).

IPCC (2019). Climate Change and Land: An IPCC Special Report on Climate Change, Desertification, Land Degradation, Sustainable Land Management, Food Security, and Greenhouse Gas Fluxes in Terrestrial Ecosystems. eds P. R. Shukla, J. Skea, E. Calvo Buendia, V. Masson-Delmotte, H.-O. Pörtner, D. C. Roberts, (Geneva, IL).

Jabbar, M. A., Saleem, M., Gebreselassie, S., and Beyene, H. (2003). Role of knowledge in the adoption of new agricultural technologies: an approach and an application. Int. J. Agricult. Res. Gover. Ecol. 2, 312-327. doi: 10.1504/IJARGE.2003.003974

James, A. R., and Harrison, M. T. (2016). Adoptability and effectiveness of livestock emission reduction techniques in Australia's temperate high-rainfall zone. Animal Product. Sci. 56, 393-401. doi: 10.1071/AN 15578

Kozachenko, C. (2020). Perceptions of Controlled Environment Agriculture: Food Security and Northern Canada. Unpublished MA Thesis, Department of Geography, Environment and Geomatics, University of Guelph. Guelp, Ontario.

Kuehne, G., Llewellyn, R., Pannell, D. J., Wilkinson, R., Dolling, P., Ouzman, J., et al. (2017). Predicting farmer uptake of new agricultural practices: a tool for research, extension and policy. Agricult. Syst. 156, 115-125. doi: 10.1016/j.agsy.2017.06.007

Kuehne, G., Nicholson, C., Robertson, M., Llewellyn, R., and McDonald, C. (2012). Engaging project proponents in R\&D evaluation using bio-economic and socio-economic tools. Agricult. Syst. 108, 94-103. doi: 10.1016/j.agsy.2012.01.009
Lindner, R. K., Pardey, P. G., and Jarrett, F. G. (1982). Distance to information source and the time lag to early adoption of trace element fertilizers. Austr. J. Agricult. Econ. 26, 98-113. doi: 10.1111/j.1467-8489.1982.tb00618.x

Natcher, D. C. (2020). Arctic Food Production: Opportunities in the North, for the North. Arctic Council - Sustainable Development Working Group, Ottawa. Available online at: https://oaarchive.arctic-council.org/handle/11374/ 2375 (accessed November 25, 2020).

Natcher, D. C., Bachmann, E., Pittman, J., Kulshreshtha, S., Baco, M. N., Akponikpe, P. B. I., et al. (2016). Knowledge diffusion and the adoption of fertilizer microdosing in Northwest Benin. Sustain. Agricult. Res. 5, 1-10. doi: $10.5539 /$ sar.v5n3p1

OECD (2019). Rethinking Innovation for a Sustainable Ocean Economy. Paris: OECD Publishing.

Pachico, D., and Fujisaka, S. (2004). Scaling Up and Out: Achieving Widespread Impact Through Agricultural Research. Cali: Centro Internacional de Agricultura Tropical (CIAT).

Pannell, D., Marshall, G., Barr, N., Curtis, A., Vanclay, F., and Wilkinson, R. (2006). Understanding and promoting adoption of conservation technologies by rural landholders. Austr. J. Experi. Agricult. 46, 1407-1424. doi: 10.1071/EA05037

Parasuraman, A., and Colby, C. C. L. (2001). Techno-Ready Marketing: How and Why Your Customers Adopt Technology. New York, NY: The Free Press, Division of Simon \& Schuster.

Rogers, E. M. (2003). Diffusion of Innovations (5th ed.). New York, NY: Free Press. Ryerson University, (2019). From Growing North to Green Iglu. Innovation Newsletter, Volume 32. Available online at: https://www.ryerson.ca/research/ publications/newsletter/2019-11/growing-north-green-iglu/ (accessed November 25, 2020).

The Growcer, (2020). Investing in Indigenous Food Sovereignty. Available online at: https://www.thegrowcer.ca/blog/2020/5/20/investing-in-indigenous-foodsovereignty (accessed November 25, 2020).

Warner, K. E. (1974). The Need for some innovative concepts in innovation: an examination of research on the diffusion of innovation. Policy Sci. 5, 433-451. doi: 10.1007/BF00147229

Weisenfeld, P., and Wetterberg, A. (2015). Technological Advances to Improve Food Security: Addressing Challenges to Adoption. Research Triangle Park, NC: RTI Press.

Conflict of Interest: CB was employed by the company Cold Acre.

The remaining authors declare that the research was conducted in the absence of any commercial or financial relationships that could be construed as a potential conflict of interest.

Copyright (c) 2021 Natcher, Ingram, Solotki, Burgess, Kulshreshtha and Vold. This is an open-access article distributed under the terms of the Creative Commons Attribution License (CC BY). The use, distribution or reproduction in other forums is permitted, provided the original author(s) and the copyright owner(s) are credited and that the original publication in this journal is cited, in accordance with accepted academic practice. No use, distribution or reproduction is permitted which does not comply with these terms. 